\title{
New Studies Initiated by the U.S. Geological Survey- Effects of Nutrient Enrichment on Stream Ecosystems
}

\author{
By Mark D. Munn and Pixie A. Hamilton
}

In 2001, the U.S. Geological Survey's National Water-Quality Assessment (NAWQA) Program began an intensive study of nutrient enrichment—elevated concentrations of nitrogen and phosphorus-in streams in five agricultural basins across the Nation (see map, p. 2). This study is providing nationally consistent and comparable data and analyses of nutrient conditions, including how these conditions vary as a result of natural and human-related factors, and how nutrient conditions affect algae and other biological communities. This information will benefit stakeholders, includ-

\section{Nutrient Issues in Surface Water}

- Nitrogen and phosphorus are essential for healthy plant and animal populations, with each water body requiring the right balance of nutrients to maintain aquatic life.

- Elevated concentrations of nutrients can lead to excessive, often unsightly, growth of aquatic plants. Overgrowth of aquatic plants can clog water-intake pipes and filters and can interfere with recreational activities, such as fishing, swimming, and boating. Subsequent decay of aquatic plants can result in foul odors and taste.

- Excessive aquatic plant growth reduces dissolved oxygen in water and alters stream habitat, both of which are critical for fish and other aquatic life. These problems occur locally and in receiving coastal waters where they can threaten fish and shellfish that are economically and ecologically important. ing the U.S. Environmental Protection Agency (USEPA) and its partners, who are developing nutrient criteria to protect the aquatic health of streams in different geographic regions.

Nutrient enrichment is one of five national priority topics addressed by NAWQA in its second decade of studies, which began in 2001. During its first round of assessments in 51 major river basins (referred to as "Study Units"), NAWQA scientists collected data on water chemistry, stream hydrology and habitat, and biological communities; currently, NAWQA is revisiting selected basins and focusing on (1) trends, (2) factors that affect water quality and aquatic health, and (3) national priority water issues related to, for example, the development of nutrient criteria, source-water protection strategies, and stream restoration plans.

The nutrient enrichment study has four major objectives that address nutrient conditions, dissolved oxygen, aquatic communities, and geographic and landscape features in agricultural basins (see inset). The focus on agricultural streams is a starting point. As the study progresses, streams draining other land uses, such as those in residential and urban areas, will likely be added.

\section{Objectives of the nutrient enrichment study}

1. Determine the total algal biomass and the abundance, type, and diversity of algal and aquatic insect communities in streams with different nutrient conditions, watershed characteristics, habitat, climate, and other natural factors.

2. Determine the interrelations among nutrient conditions, algal communi-

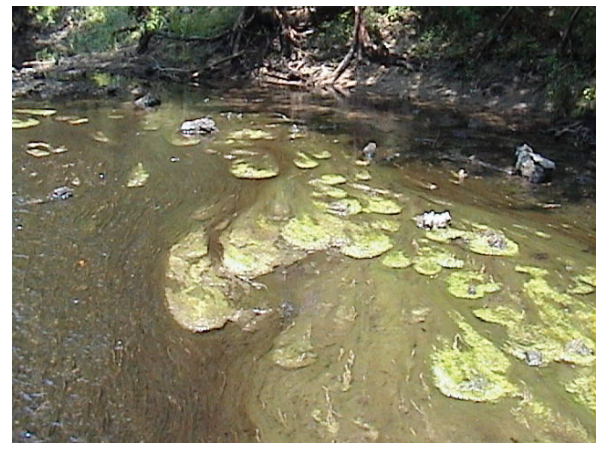

Excessive nutrients can cause overgrowth of algae and aquatic plants in streams, such as in this stream in the Apalachicola-Chattahoochee-Flint River Basins. USGS is studying nutrient enrichment and its effect on biological communities in diverse stream ecosystems across the Nation.

ties, and stream metabolism, which is defined as the gain and loss in dissolved oxygen associated with photosynthesis and plant and animal respiration. Adequate levels of dissolved oxygen are critical to fish and other aquatic life.

3. Determine the transport, chemical transformation, and retention of nutrients (referred to as "nutrient cycling") in the water column and surrounding sediments, and resulting effects on biological communities in stream reaches. Such cycling differs in different geologic and hydrologic settings, and is controlled, in large part, by groundwater and surface-water interactions.

4. Determine the extent to which associations between nutrient conditions and biological communities occur over geographic regions that share common natural features, landscape characteristics, and biological communities. 


\section{What is nutrient enrichment?}

Although the term "enrichment" usually has positive connotations, nutrient enrichment in our rivers, lakes, and estuaries is causing substantial ecological and economic problems across the nutrients can lead to excessive and often unsightly growth of aquatic plants (algae and other plants). These plants can clog water-intake pipes and filters and interfere with fishing, swimming, and boating. Decaying aquatic plants can produce foul odors and can affect how water tastes. By decreasing oxygen concentrations and altering stream habitat in the water, aquatic plant overgrowth also can be harmful to fish and other aquatic organisms.

Nutrient enrichment and its associated problems can extend from local waters to downstream waters, including coastal environments. For example, elevated nutrient concentrations in streams throughout the Midwest contribute to water-quality problems in the Gulf of Mexico. Estuarine and shallow marine environments in the Gulf often are impaired by massive algal blooms, largescale oxygen "dead zones," degraded sea grass beds and coral reefs, and outbreaks of harmful organisms. The consequences include losses to aquatic life, which affects fishing and other water industries, reduced recreational opportunities, and a lower aesthetic quality of our waters.

A 1998 national inventory of water quality conducted by States and Tribes found that nutrients were a leading cause of water-quality impairment in our rivers, Nation. These elevated concentrations of

lakes, and estuaries. Elevated concentrations of nutrients were found in 10 percent of assessed rivers and streams (about 840,000 river and stream miles were assessed), and contributed to 30 percent of reported water-quality problems in the impaired rivers and streams (about 291,000 miles). In 2000, the inventory found that nutrients were still a concern; as in 1998, runoff from agricultural land, which commonly carries with it high concentrations of nutrients, was the number one cause of water-quality problems in assessed rivers and streams (about 700,000 river and stream miles were assessed) (U.S. Environmental Protection Agency, 2000; 2002).

\section{Responding to the Nutrient Enrichment Problem}

It has been difficult to craft a national response to this issue, such as a set of widely applicable management strategies and policies, because nutrient enrichment is widespread, complex, and highly variable. Nutrient conditions-a term that encompasses sources of nutrients, their concentrations in soil and water, their transport, and their uptake by plants and animals - vary seasonally and among watersheds. Nutrient conditions are affected by climate, soil type, amount of ground-water discharge to streams, characteristics of the streambed, amount of riparian shading, physical disturbance of stream habitat, and biological organisms. How streams respond to nutrient enrichment varies depending on these factors, and the rate at which streams can recover following implementation of management strategies also varies.

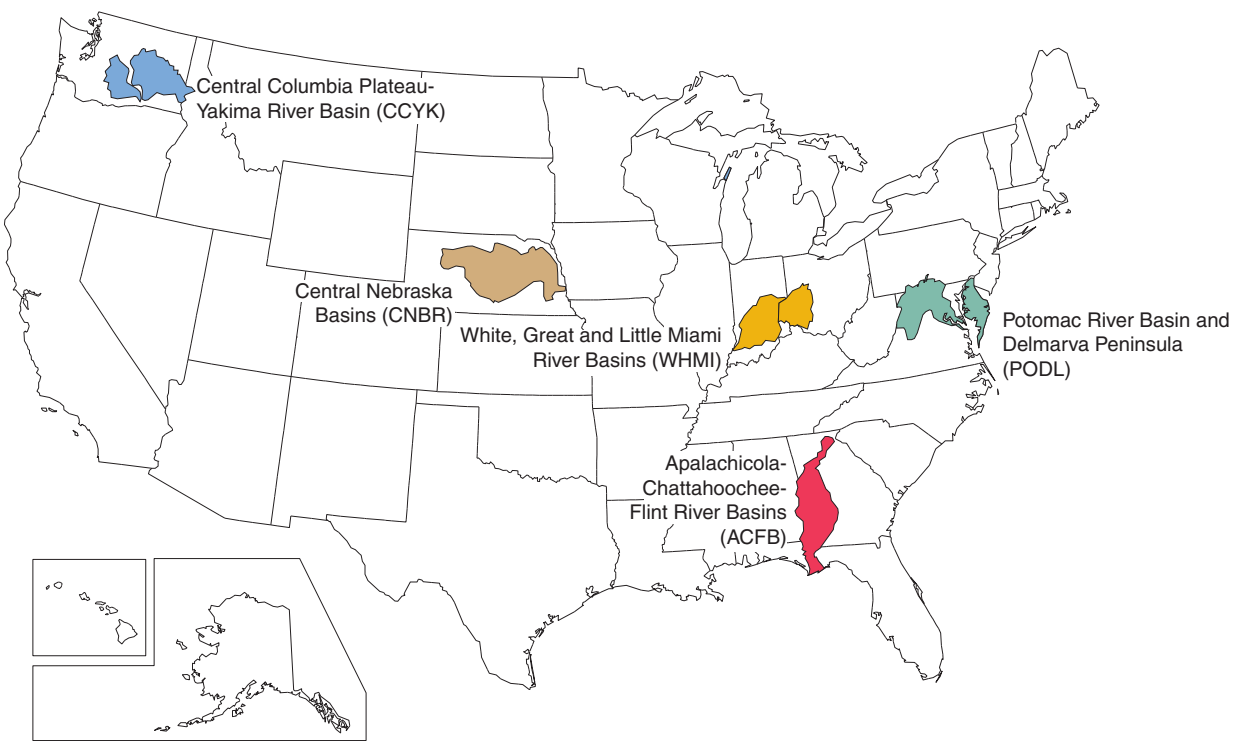

Nutrients are studied in stream ecosystems across the Nation

The five Study Units (including parts of nine States) in the nutrient enrichment study are the Apalachicola-Chattahoochee-Flint River Basins (Georgia and Florida); Central Columbia Plateau-Yakima River Basin (Washington); Central Nebraska Basins (Nebraska); Potomac River Basin and Delmarva Peninsula (Maryland, Delaware, and Virginia); and the White, Great and Little Miami River Basins (Indiana and Ohio). Similar studies in additional basins will begin in 2004 and 2007. A consistent, two-fold study approach is being used.

First, streamflow, nutrient concentrations and other chemical characteristics, dissolved oxygen concentrations, biological communities, and stream and riparian habitat are assessed at 25-30 sites within each Study Unit. Data from these one-time "snapshot" assessments will be used to define relations among nutrients, stream metabolism, and biological communities in diverse environmental settings (study objectives 1 and 2, see p.1), and to aid in statistical analyses for regionalization of nutrient conditions (objective 4).

Second, processes controlling stream metabolism and nutrient cycling (which includes transport, transformation, and retention) are being assessed in a single stream reach within three of the five Study Units. These more detailed, smallscale studies will help to determine the effects of these processes on biological communities (objectives 2 and 3), and help to identify environmental settings that have chemical, physical, and biological characteristics associated with nutrient enrichment (objective 4).

Effects of nutrient enrichment on stream ecosystems are being investigated in 5 of 14 NAWQA Study Units: the Apalachicola-Chattahoochee-Flint River Basins; Central Columbia Plateau-Yakima River Basin; Central Nebraska Basins; Potomac River Basin and Delmarva Peninsula; and the White, Great and Little Miami River Basins. 


\section{How USGS information is used}

\section{Improved standards and guidelines for} protecting aquatic and human health

As of 2003, only one enforceable national standard for nutrients exists- 10 milligrams per liter of nitrate (as nitrogen) in drinking water- to protect human health. USEPA has established a nonregulatory desired goal of 0.1 milligram per liter of total phosphorus in surface water-to prevent overgrowth of algae and aquatic plants in streams and other flowing waters not discharging to lakes or impoundments. USEPA is continuing to develop criteria for total phosphorus and total nitrogen in streams for the protection of aquatic and human health, and is focusing on different geographic regions and types of water bodies; the goal is to have criteria that are congruent with State water-quality standards. USGS findings on nutrient conditions, biological communities, stream characteristics, and environmental settings are being used in the development of these regional nutrient criteria.

\section{Improved State assessments of beneficial uses and impaired streams}

States and Tribes use USGS nutrient findings for state assessments of ben-

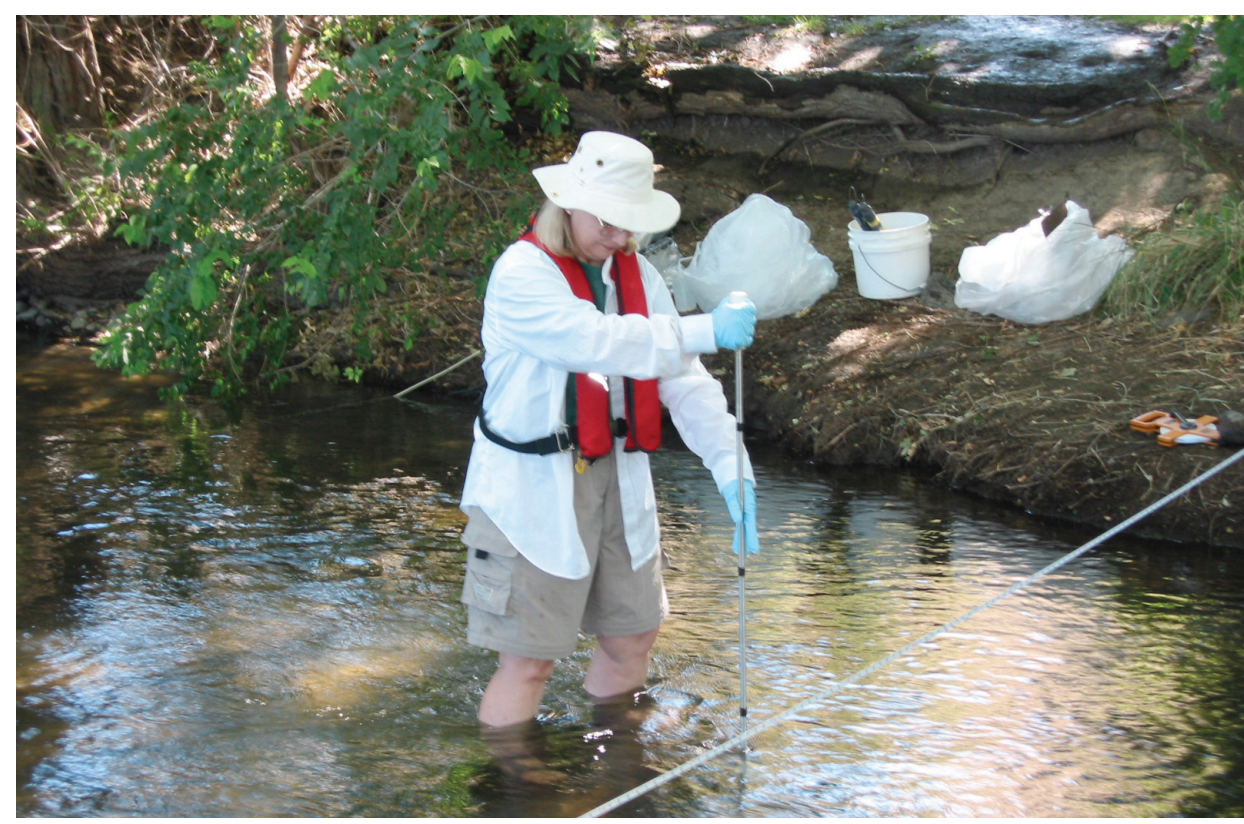

Data on streamflow, nutrient concentrations and other chemical characteristics, dissolved oxygen, biological communities, and stream and riparian habitat are collected at 25-30 sites within each of the Study Units.

eficial uses of streams for aquatic life, recreation, and drinking water (required in USEPA 305(b) reports), and to help determine the level of stream impairment (required in USEPA 303(d) reports). For example, the New Jersey Department of Environmental Protection used NAWQA findings in preparing their 305(b) reports, which documented long-term trends in nitrate contamination and changes in stream conditions and fish communities in northern New Jersey as a result of improved wastewater treatment. USGS findings on nutrient concentrations,

The five Study Units

settings (climate, geology, topography, and soils) and agricultural practices (crop and animal production and irrigation and drainage practices)

\begin{tabular}{|c|c|c|c|c|}
\hline Study Unit & $\begin{array}{l}\text { Major crop and animal } \\
\text { production }\end{array}$ & $\begin{array}{c}\text { Primary agricultural } \\
\text { management practices }\end{array}$ & Hydrologic setting & $\begin{array}{l}\text { Key factors affecting } \\
\text { nutrient transport }\end{array}$ \\
\hline $\begin{array}{l}\text { Apalachicola- } \\
\text { Chattahoochee-Flint } \\
\text { River Basins }\end{array}$ & Row crops and poultry & $\begin{array}{l}\text { Moderate irrigation } \\
\text { (center pivot); wide- } \\
\text { spread use of modified } \\
\text { ditches and dredged and } \\
\text { channeled streams }\end{array}$ & $\begin{array}{l}\text { Humid; moderately per- } \\
\text { meable soils }\end{array}$ & $\begin{array}{l}\text { Relatively intact and ex- } \\
\text { tensive riparian zones and } \\
\text { forested wetlands; ground- } \\
\text { water discharge }\end{array}$ \\
\hline $\begin{array}{l}\text { Central Columbia Plateau- } \\
\text { Yakima River Basin }\end{array}$ & $\begin{array}{l}\text { Cattle grazing, row crops, } \\
\text { orchards, vineyards, and } \\
\text { some dairy }\end{array}$ & $\begin{array}{l}\text { Irrigation (pivot, furrow, } \\
\text { and drip); widespread } \\
\text { use of irrigation canals } \\
\text { and artificial drainage }\end{array}$ & $\begin{array}{l}\text { Arid; deep loess soils } \\
\text { underlain by basalt }\end{array}$ & $\begin{array}{l}\text { High hydrologic manage- } \\
\text { ment (irrigation withdrawals } \\
\text { and return flows); seasonal } \\
\text { variability in turbidity, flow, } \\
\text { and ground-water discharge; } \\
\text { limited stream shading }\end{array}$ \\
\hline Central Nebraska Basins & $\begin{array}{l}\text { Row crops and some } \\
\text { dairy }\end{array}$ & Center pivot irrigation & $\begin{array}{l}\text { Semiarid; permeable } \\
\text { surface and subsurface }\end{array}$ & $\begin{array}{l}\text { Ground-water discharge; } \\
\text { poorly shaded streams with } \\
\text { seasonally high turbidity }\end{array}$ \\
\hline $\begin{array}{l}\text { Potomac River Basin and } \\
\text { Delmarva Peninsula }\end{array}$ & $\begin{array}{l}\text { Row crops, poultry, and } \\
\text { some dairy }\end{array}$ & $\begin{array}{l}\text { Tillage and no tillage; } \\
\text { some center pivot ir- } \\
\text { rigation }\end{array}$ & $\begin{array}{l}\text { Humid; moderately to } \\
\text { well-drained soils; per- } \\
\text { meable sand and gravel } \\
\text { surficial aquifer }\end{array}$ & $\begin{array}{l}\text { Ground-water discharge with } \\
\text { low turbidity and well-shad- } \\
\text { ed streams }\end{array}$ \\
\hline $\begin{array}{l}\text { White, Great and Little } \\
\text { Miami River Basins }\end{array}$ & Row crops & $\begin{array}{l}\text { Tillage and no tillage; } \\
\text { widespread use of artifi- } \\
\text { cial drainage (tile drains } \\
\text { and ditches) }\end{array}$ & $\begin{array}{l}\text { Humid; poorly-drained } \\
\text { soils; relatively imper- } \\
\text { meable glacial till and } \\
\text { sediment }\end{array}$ & $\begin{array}{l}\text { Overland runoff; tile drains; } \\
\text { highly turbid streams }\end{array}$ \\
\hline
\end{tabular}




\section{The NAWQA Program}

USGS nutrient enrichment studies are planned and implemented through the National Water-Quality Assessment (NAWQA) Program (a map is available at http://water.usgs.gov/nawqa). In 1991, NAWQA began evaluating the quality of streams, ground water, and aquatic ecosystems in 51 major river basins and aquifer systems (known as "Study Units") across the Nation. The assessments characterize the ambient water resource-the source of about 60 percent of the Nation's drinking water and water for industrial, irrigation, and recreational uses. During its first decade, NAWQA made baseline assessments of pesticides, nutrients, volatile organic compounds, trace elements, dissolved solids, and radon, as well as the condition of aquatic habitats and fish, insect, and algal communities. These findings are described in numerous reports (these reports can be accessed at the NAWQA Web site above).

During the next decade of studies, 42 of the Study Units will be intensively reassessed to determine trends at many of the streams and ground-water monitoring sites; fill critical gaps in characterizing water-quality conditions; and build upon earlier NAWQA findings that show how natural features and human activities affect water quality and aquatic ecosystems. Nutrient enrichment is one of five national priority topics that will be addressed in the second decade of NAWQA studies. The four other topics include (1) effects of urbanization on stream ecosystems; (2) bioaccumulation of mercury in stream ecosystems; (3) transport of contaminants to public-supply wells; and (4) sources, transport, and fate of agricultural chemicals.

sources, transport, and loads also can help in the development of TMDLs, or Total Maximum Daily Loads. NAWQA findings on naturally elevated concentrations of phosphorus transported in ground water to surface water in parts of the Albemarle-Pamlico Sound Drainage Basins were used in developing TMDLs for selected North Carolina streams.

\section{Improved ecological indicators and monitoring}

USGS assessments are useful in identifying ecological indicators of nutrient enrichment and associated water-quality issues. Improved understanding of key indicators will help water managers prioritize streams for protection and restoration, reduce monitoring costs, and evaluate strategies for reducing nutrients in streams. USGS nutrient assessments also can help to determine whether biological assessment techniques used by States, consultants, and other stakeholders are sufficient for evaluating the health of streams and restoration efforts.

\section{Improved identification of high-priority streams, regions, and appropriate management strategies}

USGS assessments of regional variations in nutrient conditions can help resource managers establish and prioritize streams

\section{For additional information and questions, please contact:}

Mark D. Munn, Team Leader, Nutrient Enrichment Effects study (253) 428-3600 ext. 2686 mdmunn@usgs.gov

W. Brian Hughes, Lead Scientist, Apalachicola-ChattahoocheeFlint River Basins (770) 903-9162 wbhughes@usgs.gov http://ga.water.usgs.gov/nawqa/

Robert W. Black, Lead Scientist, Central Columbia Plateau-Yakima River Basin (253) 428-3600 ext. 2687 rwblack@usgs.gov http://wa.water.usgs.gov/projects/ccyk/

Ronald B. Zelt, Lead Scientist, Central Nebraska Basins (402) 437-5157 rbzelt@usgs.gov http://ne.water.usgs.gov/Nawqa/index. htm

Judith M. Denver, Lead Scientist, Potomac River Basin and Delmarva Peninsula (302) 734-2506 ext. 229 jmdenver@usgs.gov http://md.water.usgs.gov/pnawqa/ agement, leading to more focused and effective strategies and monitoring. The findings also can help managers design more effective strategies for nutrient management. For example, understanding the relative effects of nutrient enrichment and physical stream disturbance on biological communities can help water managers decide whether to direct resources towards managing chemical use and nutrients or towards restoring stream habitat.

\section{The USGS promotes public access to water-quality information}

Visit the NAWQA Web site to access reports, water-quality data, and maps:

http://water.usgs.gov/nawqa

Visit the EPA Web site to access information on nutrient criteria:

http://www.epa.gov/waterscience/standards/nutrient.html

and for biennial national water quality inventory reports:

http://www.epa.gov/305b/
Jeffrey W. Frey, Lead Scientist, White, Great and Little Miami River Basins (317) 290-3333 ext. 151 jwfrey@usgs.gov http://in.water.usgs.gov/nawqa/ wrnawqa.htm

\section{Literature cited}

U.S. Environmental Protection Agency, 2000, National Water Quality Inventory: 1998 Report, U.S. Environmental Protection Agency Report EPA-841R-00-001, Washington, D. C.

U.S. Environmental Protection Agency, 2002, National Water Quality Inventory: 2000 Report, U.S. Environmental Protection Agency Report EPA-841R-02-001, Washington, D. C. 